\title{
ПОНЯТТЯ «ПРАВОВОГО СТАТУСУ ОСОБИ» ЯК МЕТОДОЛОГІЧА ОСНОВА ДЛЯ ДОСЛІДЖЕННЯ СТАТУСУ УЧАСНИКІВ КОНСТИТУЦІЙНОГО ПРОВАДЖЕННЯ
}

\begin{abstract}
РОЗВАДОВСБКИЙ Володимир Іванович - кандидат юридичних наук, доцент, завідувач кафедри конституційного, міжнародного та адміністративного права Юридичного інституту Прикарпатського національного університету імені Василя Стефаника
\end{abstract}

DOI:10.32782/NP.2019.4.1

Статья посвящена вопросам влияния понятия правового статуса на бормирование содержания правовой категории «конституционно-правовой статус участника конституичионого производства». По мнению автора, понятие «правовой статус личности» является общим понятием. Родовъм понятием является понятие «специиальный правовой статус», а в качестве видового понятия въгтупает категория «индивидуальнъий правовой статус». С учетом соотношения общего родового и видового понятий определяется содержание спечиализированной правовой категории «конституционно-правовой статус участника конституиионного производства».

Ключевъие слова: личность, участник производства, правовое положение личности, правовой статус личности, специальный правовой статус, индивидуальньий правовой статус, участник конституционного производства, конституционно-правовой статус участника конституционного производства.

Постановка проблеми

Питання про важливість правових статусів у цілому та правового статусу учасників конституційного провадження зокрема викликає ряд наукових дискусій серед учених. У сучасній вітчизняній юридичній літературі правовий статус особи розглядається на трьох рівнях: загальний (конституційний) статус громадянина України, спеціальний та індивідуальний (конкретний) статуси. Такий підхід до дослідження правових статусів грунтується на співвід- ношенні філософських категорій загального, особливого та одиничного і $є$ сьогодні досить перспективним, оскільки дає змогу простежити діалектику правового статусу особи на різних рівнях правового регулювання. При цьому в ролі загального виступає статус усіх громадян України, особливого - спеціальний статус, одиничного - індивідуальний (конкретний) статус особи.

Необхідно згадати про рухомість правового статусу, що змінюється у разі його переходу із загального (конституційного) в спеціальний, а із спеціального - в індивідуальний. Усе це відбувається за рахунок зміни змісту елементів, що збагачуються внаслідок конкретизації. За своїм структурним складом статус залишається незмінним, тому що він $\epsilon$ вираженням певних зв'язків і відносин громадянина із суспільством та державою. Загальний, спеціальний та індивідуальний статуси відображають лише різні рівні цих зв'язків і відносин.

у контексті усього вищенаведеного важливе місце тут займає проблема статусу учасників конституційного провадження як у частині їі статики, так і динаміки.

\section{Стан дослідження}

Питання правового статусу особи в цілому та їх конституційно-правового статусу зокрема у тій чи іншій мірі досліджували Н. Вітрук, В. Котюк, С. Аукашева, О. Марцеляк, Н. Матузов, Н. Оніщенко, В. Патюлін, М. Строгович та інші науковці. Проте окремого дослідження потребує пробле- 


\section{Теорія, історія держави і права, конституційне право}

матика співвідношення правового статусу особи та статусу учасників конституційного провадження у науково-методологічному розумінні.

\section{Постановка завдання}

Враховуючи все вищенаведене, метою зазначеної статті є висвітлення змісту поняття «правового статусу особи» як методологічної основи для дослідження статусу учасників конституційного провадження.

\section{Виклад основного матеріалу дослідження}

У праві є сталі категорії, науково обгрунтовані досить давно. Однією з них, як видається, мала б бути категорія «правовий статус», оскільки про роль права в житті людини і місце людини в праві наукові дискусії тривають уже сторіччями, від початку існування самого права, а можливо, й філософії. Як слушно зауважують науковці, правовий статус - це одна 3 найважливіших політико-юридичних категорій, яка «зв’язана нерозривно з соціальною структурою суспільства, рівнем демократії, станом законності» [1, с. 91].

Перші згадки про юридичний (правовий) статус були ще в працях давньоримських учених. За допомогою цього терміна вони сформулювали категорії, що відображають окремі аспекти правового становища людини: стан свободи - status libertatus, стан громадянства - status civitatus, сімейний стан - status familiae [2, с. 98].

Поняття «правовий статус» активно використовується в юридичній науці, однак серед науковців відсутній єдиний підхід до визначення вказаного поняття. На думку Н. М. Оніщенко, під правовим статусом слід розуміти систему законодавчо встановлених та гарантованих державою прав, свобод, законних інтересів і обов'язків суб'єкта суспільних відносин [3, с. 366]. У свою чергу, О. Ф. Скакун визначає правовий статус особи як передбачену законодавством систему взаємозалежних прав, законних інтересів і обов'язків суб'єкта права [4 с. 569]. На іï переконання, правовий статус - це система закріплених у нормативно-правових актах i гарантованих державою прав, свобод, обов'язків, відповідальності, відповідно до яких індивід як суб'єкт права (тобто як такий, що має правосуб'єктність) координує свою поведінку в суспільстві [5, с. 402].

С. ᄉ. Аисенков розглядав правовий статус особи як сукупність закріплених у чинному законодавстві прав, свобод та обов'язків, а також гарантій їх реалізації [6, с. 258].

M. В. Кравчук пропонуе під правовим статусом особи розуміти сукупність або систему всіх належних громадянину суб'єктивних юридичних прав, свобод i обов'язків, що визначають його правове становище в суспільстві, яке закріплене в чинному законодавстві та інших формах права [7, с. 46].

Схожої позиції тримається К. Г. Волинка, на думку якої правовий статус особи - це система взаємопов'язаних прав і свобод та обов'язків, які закріплені в законодавстві і визначають правове положення особи в суспільстві [8, с. 207]. О. І. Осауленко приєднується до думки вчених-правознавців та зауважує, що у найбільш узагальненому вигляді правовий статус особи визначається як юридичне закріплення становища особи в суспільстві. Учений зазначає, що в основі правового статусу лежить фактичний соціальний статус, тобто реальне становище людини в конкретній системі суспільних відносин [9, с. 280]. Право лише закріплює це становище, вводить його в законодавчі рамки. Відповідно соціальний і правовий статуси співвідносяться між собою як зміст і форма. Тому об'єднавчою категорією цих понять є поняття соціальнонормативного статусу, тобто такого, який визначається відповідними соціальними нормами і відносинами. У свою чергу, його найбільш важливою органічною частиною надалі став правовий статус.

Правовий статус є серцевиною нормативного вираження основних принципів взаємовідносин між особою і державою; системою еталонів та зразків поведінки людей, яка заохочується і захищається від порушень державою і, як правило, схвалюється суспільством. 
В. О. Котюк під правовим статусом особи розуміє сукупність юридичних прав, свобод та обов'язків особи, які закріплені в чинному законодавстві й становлять соціально допустимі та необхідні потенційні можливості особи мати суб'єктивні права й обов'язки, реалізувати їх у системі суспільних відносин [10, с. 100-102].

М. І. Матузов підкреслює, що правовий статус «охоплюе, по суті, всю сферу юридичних зв'язків і відносин між особистістю й суспільством. Усе те, що так чи інакше законодавчо визначає й закріплює (оформлює) становище особистості в суспільстві, входить у поняття правового статусу» [11, с. 191-192].

Порівняння різних підходів до поняття правового статусу особи дає змогу дійти висновку, що, незважаючи на певні відмінності в дефініціях учених щодо категорії «правовий статус особи», його сутністною характеристикою є комплекс суб'єктивних юридичних прав та обов'язків особи. Відповідно, найдоцільнішою, на нашу думку, $\epsilon$ дефініція $\lambda$. А. Ауць, яка під правовим статусом особи розуміє закріплені у відповідних джерелах права й гарантовані державою суб'єктивні права та юридичні обов'язки особи [12, с. 124].

Поняття «правовий статус» і «правове становище» (у перекладі 3 латинської означає «положення, стан кого-небудь або чого-небудь, а також становище») розуміється як загальне становище окремої особи (особистості) в суспільстві, сукупність ycix (або частини) їі юридичних прав та обов'язків [8, с. 300]. Зважаючи на такий неоднозначний переклад, у науковій літературі існує дискусія щодо того, чи є тотожними поняття «правовий статус» i «правове становище». Більшість учених уважає ці поняття тотожними й не вбачають практичної чи теоретичної необхідності в ïх розмежуванні, оскільки поняття «правовий статус» $\mathrm{i}$ «правове становище» 3бігаються й за етимологією, і за змістом [13, с. 224-225]. В. І. Новосьолов [14, с. 23] на підтвердження такого розуміння, зокрема, наводить аргумент, що законодавство, юридична практика, друковані джерела, а також міжнародні акти про права людини не проводять між цими поняттями будьяких відмінностей, уживаючи їх в одному й тому ж значенні. Ці поняття взаємозамінні, залежно від контексту може застосовуватися той чи інший термін. Зокрема, таку точку зору підтримують М. I. Матузов, С. В. Черниченко, А. Д. Воєводін, В. А. Карташкін та інші.

У зміст правового статусу поряд із юридичними правами й обов'язками деякими вченими включаються менші за обсягом категорії, такі як громадянство [15, с. 3-11], гарантії $\lambda$. Д. Воєводін [16], відповідальність громадянина перед державою й суспільством [17, с. 13] (М. І. Матузов) [18], конституційно закріплений принцип рівноправності громадян [19, с. 230], правові гарантії та правова відповідальність за виконання обов'язків [20], правоздатність [21, с. 4] та інші.

Отже, зміст правового становища (статусу) особи вищевказані автори визначають як складне явище, що органічно поєднує як соціальний, так і юридичний аспекти, і розділяти поняття «правовий статус» $\mathrm{i}$ «правове становище»недоцільно.

Н. В. Вітрук уважає, що вищевказані спроби вчених під час характеристики правового статусу особистості в широкому плані вийти за рамки тільки системи юридичних прав і обов'язків $\epsilon$, безсумнівно, позитивним моментом, проте новий підхід до змісту цього явища вони прагнуть здійснити в рамках традиційного понятійного апарату, зокрема, за рахунок розширення вже відомого науці поняття правового статусу особи як системи юридичних прав і обов'язків. Він зауважує, що більш правильно розрізняти два самостійних поняття - «правий статус (становище) особи» в широкому значенні i «правовий статус (становище) особи» у вузькому значенні як взаємопов'язані явища, реальний зв’язок між якими можна визначити як відношення цілого й частини [22, с. 11]. Умовно суто термінологічно перше поняття можна позначити як «правове становище», а друге - як «правовий статус» (незважаючи на етимологічну тотожність термінів «становище» і «статус») [22, с. 25-26]. Трохи далі по тексту науковець пояснює свою думку: 


\section{Теорія, історія держави і права, конституційне право}

«Ядро, основу правового становища особи становить система юридичних прав, свобод, обов'язків і законних інтересів особи в їх єдності, тобто правовий статус особи. Структурними елементами правового становища особи є громадянство i правосуб'єктність як необхідні умови володіння правовим статусом особи, а також юридичні гарантії правового статусу особи. Особливим, специфічним елементом правового становища особи та його структурних складових є принципи, закріплені в законі або такі, що випливають із правової природи відносин особи, суспільства й держави, котрі визначають сутність і зміст правового становища особи та його структурних елементів» [22,с. 22].

На нашу думку, поняття «правовий статус» $\mathrm{i}$ «правове становище» $е$ тотожними. Тут не можна не погодитися 3 думкою M. I. Матузова про те, що «в такому поділі немає особливої необхідності, оскільки полісемантичність, смислове подвоєння терміна не сприяє чіткому сприйняттю й аналізу однієї з ключових категорій правознавства. Різницю варто проводити не між правовим статусом і правовим становищем однієї й тієї ж особи, а між правовим статусом (становищем) різних осіб або організацій» [23, с. 265]. Нема будь-якої теоретичної чи практичної необхідності розрізняти поняття «правовий статус» $\mathrm{i}$ «правове становище» особи, адже ці поняття ідентичні, спроби їх розмежування виглядають штучними. Статус - це і є становище, стан когонебудь або чого-небудь. Етимологічно й по суті вони збігаються [24, с. 140].

Отже, повне, реальне уявлення про права і свободи людини та громадянина взагалі та окремих категорій громадян зокрема неможливо отримати без розгляду їх у складі правового становища (статусу) особи.

У юридичній літературі поняття правового статусу і правового становища розглядаються по-різному. Одна група дослідників вважає, що ці поняття є тотожними, інша - що поняття правового становища 6 ширшим, ніж поняття правового статусу особи. Деякі автори вважають, що навпаки. Різний підхід до розгляду сутності понять «правовий статус» та «правове становище» не змінює реального становища будь-якої людини в суспільстві, яке закріплене в правових нормах, тому мають рацію ті автори, які вважають, що між змістом цих понять різниці немає, і вони розглядаються як однопорядкові та з позиції формальної логіки є тотожними. Відмінність необхідно шукати не між правовим статусом і правовим становищем однієї й тієї самої особи, а між правовим статусом (становищем) різних осіб.

Отже, розглядаючи поняття правового становища і правового статусу особи як тотожні, можна визначити основні ознаки цього поняття:

1) ця категорія має узагальнений, універсальний характер. Вона немовби вбирає в себе правові статуси різних категорій ociб;

2) дана категорія відображає індивідуальні особливості людини і реальне становище їі в системі різноманітних суспільних відносин;

3) права і свободи осіб, що становлять основу їх правового статусу, не можуть бути реалізовані без інших його компонентів: без кореспондуючих правам обов'язків, без юридичної відповідальності в необхідних випадках, без правових гарантій забезпечення прав і свобод тощо;

4) категорія правового статусу дає змогу досліджувати права, свободи та обов'язки осіб як систему, проводити порівняння статусів різних категорій осіб.

\section{Висновки}

Отже, питання про поняття «правовий статус» у правовій доктрині є дискусійним, що обумовлено перш за все тим, що правовий статус є багатоаспектною та комплексною правовою категорією, що має певну структуру та за допомогою якої особа координує свою поведінку в суспільстві.

Проте також слід зазначити, що вищенаведене поняття 6 найзагальнішою правовою категорією, яка обумовлює наступне: 1) родовим відносно нього є поняття «спеціальний правовий статус»; 2) у якості видового поняття виступає категорія «індивідуальний правовий статус»; 3) 3 ура- 
хуванням співвідношення загального поняття «правовий статус», родового поняття «спеціальний правовий статус» та видового поняття «індивідуальний правовий статус» визначається зміст спеціалізованої правової категорії «конституційно-правовий статус учасника конституційного провадження».

\section{Література}

1. Аукашева Е. А. Правовой статус человека и гражданина / Е. А. Аукашева // Права человека. - М. : Издательский дом NOTA BENE, 2000. - 576 с.

2. Шайкенов Н. А. Правовое обеспечение интересов личности / Н. А. Шайкенов. - Свердловск : Изд-во Урал. ун-та, 1990. - 200 с.

3. Оніщенко Н. М. Теорія держави і права: Академічний курс : підручник / Н. М. Оніщенко, О. В. Зайчук. - К. : Юрінком Інтер, 2008. - 688 с.

4. Скакун О. Ф. Теорія держави і права (Енциклопедичний курс) : підручник /О. Ф. Скакун. - Х. : Еспада, 2006. - 776 с.

5. Скакун О. Ф. Теорія держави і права : підручник / О. Ф. Скакун. - Х. : Консум, 2001. - 656 с.

6. Аисенков С. А. Загальна теорія держави і права : навчальний посібник. - К. : Юрисконсульт, 2006. - 355 с.

7. Кравчук М. В. Теорія держави i права : навчальний посібник / М. В. Кравчук. - Тернопіль : Економічна думка, 1999. - 114 с.

8. Волинка К. Г. Теорія держави i права : навчальний посібник / К. Г. Волинка. - К. : МАУП, 2003. - 240 с.

9. Осауленко О. І. Загальна теорія держави і права : навчальний посібник / O. I. Осауленко. - К. : Істина, 2007. - 336 с.

10. Котюк В. О. Теорія права : [навчальний посібник] / В. О. Котюк. - К. : Вентурі, 1996. - 208 с.

11. Матузов Н. И. Аичность. Права. Демократия: Теоретические проблемы субъективного права / Н. И. Матузов. - Саратов: Издательство Саратовского университета, 1972. - 292 с.

12. Ауць А. А. Загальна теорія держави та права : [навчально-методичний посібник (за кредитно-модульною системою)] / $\lambda$. А. Ауць. - К. : Атіка, 2007. -412 с.

13. Матузов Н. И. Правовой статус личности: понятие, структура / Н. И. Матузов // Правопорядок и правовой статус личности в развитом социалистическом обществе в свете Конституции СССР 1977 года. - Саратов : Издательство Саратовского университета, 1976. - С. 224-225.

14. Новоселов В.И. Правовое положение граждан в социалистическом государственном управлений / В.И. Новоселов. Саратов : Издательство Саратовского университета, 1976. - 216 с.

15. Лепешкин А.И. Правовое положение советских граждан / А. И. Лепешкин. - М. : Мысль, 1966. - 56 с.

16. Воеводин $\lambda$. Д. Содержание правового положения личности в науке советского государственного права / Л. Д. Воєводин // Сов. государство и право. - 1965. - №2. - C. 42-50.

17. Горшенев В. М. Способы организации формы правового регулирования в современный период коммунистического строительства : автореф. дисс. ... докт. юрид. Наук / В.М. Горшенев. - Свердловск, 1969.

18. Матузов Н. И. Правовая система и личность / Н. И. Матузов. - Саратов, 1987. -293 c.

19. Патюлин В. А. Государство и личность в СССР (правовые аспекты взаимоотношений) / В. А. Патюлин. - М. : Наука, 1974. - 245 c.

20. Строгович М. С. Вопроси теории прав личности / М. С. Строгович // Философия и современность. - М., 1976. -С. 33-35.

21. Щетинин В. В. Гражданин и социалистическое государство / В. В. Щетинин // Сов. государство и право. - 1975. - № 2. - С. 3-10.

22. Витрук Н. В. Общая теория правового положения личности / Н. В. Витрук. - М. : Норма, 2008. - 448 с.

23. Теория государства и права : [курс лекций] / Под ред. Н. И. Матузова иА. В. Малько. - 2-е изд., перераб. и доп. М. : Юристь, 2001. - 776 с. 


\section{АНОТАЦІЯ}

Стаття присвячена питанням впливу поняття «правовий статус особи»на бормування змісту правовой категорї «конституиійно-правовий статус учасника конституизйного провадження». На думку автора, поняття «правовий статус особи» є загальним поняттям. Родовим поняттям $є$ поняття "спеціальний правовий статус», а у якості видового поняття виступає категорія «індивідуальний правовий статус». 3 урахуванням співвідношення загального родового та видового понять визначається зміст спеціальної правової категоріӥ «конституиійно-правовий статус учасника конституиійного провадження».

Ключові слова: особа, учасник провадження, правове становище особи, правовий статус особи, спеціальний правовий статус, індивідуальний правовий статус, учасник конституиійного провадження, конституиійноправовий статус учасника конституційного провадження.

24. Комаров С. А. Общая теория государства и права : [учебник] / С. А. Комаров. - 4-е изд., перераб. и доп. М. : Юрайт, 1998. - 416 с.
Rozvadovsky V.I.

The concept of "legal status of a person" as a methodological basis for the study of the status of participants in constitutional proceedings

The article deals with the influence of the concept of "legal status of a person" on the formation of the content of the legal category "constitutional legal status of a participant in constitutional proceedings". According to the author, the concept of "legal status of a person" is a general concept. The generic concept is the concept of "special legal status", and the category "individual legal status" is a species concept. Taking into account the correlation of general generic and species concepts, the content of the specialized legal category is determined "constitutional and legal status of the participant of constitutional proceedings".

Keywords: person, party to proceedings, legal position of person, legal status of person, special legal status, individual legal status, party to constitutional proceedings, constitutional and legal status of party to constitutional proceedings. 